\title{
Determination of the parameters of local reinforced zones under the protection means
}

\author{
Serhii Nehrii $^{1,}{ }^{*}$, Tetiana Nehrii $^{1}$, Oksana Zolotarova ${ }^{1}$, Khairulla Aben $^{2}$ and Khalidilla Yussupov $^{3}$ \\ ${ }^{1}$ Donetsk National Technical University, 85300, Pokrovsk, Shybankova Sq., 2, Ukraine \\ ${ }^{2}$ KAZ Minerals, 050020, Almaty, Omarovoi, 8, Kazakhstan \\ ${ }^{3}$ Satbayev University, 050013, Almaty, Satpayeva, 22a, Kazakhstan
}

\begin{abstract}
In order to develop effective measures to ensure the operational condition of the development workings behind the face in the conditions of soft footwall rocks, the construction of local reinforced zones under the protection means has been proposed. The presence of such zones allows transferring the current load deep into the massif and creating a stable foundation under the protective structure. The results of researches concerning establishment of rational parameters of local reinforced zones with application of the method of finite elements, the method of experiment planning and the method of statistical processing of these results have been presented. The empirical dependence of the subsidence of the local reinforced footwall under the protection means on their load, deformation characteristics of the local reinforced zone and host rocks, width of protection means, strength of soft underlying rocks and geometric dimensions of the zone has been determined. The relative indicator of efficiency of local strengthening of a footwall which is used for determining of rational parameters of a locally reinforced zone has been offered.
\end{abstract}

\section{Introduction}

Recently, there has been a tendency in Ukraine to reduce coal consumption and switch to alternative energy sources. But coal will not lose its relevance because of its strategic importance to the state, as thermal power plants account for $31 \%$ of electricity generation. Nuclear generation has the largest share (55.6\%), but it is importdependent due to the impossibility of having a closed nuclear fuel cycle within the country [1]. Therefore, the replacement of thermal energy with nuclear energy makes our country energy-dependent.

It is impossible to completely copy the models of European economies, as the level of development of industries, raw materials base, and export and import orientation in Ukraine differ significantly. It is unacceptable that a state that has its own coal resources exports it from Russia and Kazakhstan. In Kazakhstan coal still remains and will definitely remain the main source of energy in the near future, despite the fact that the country is a world leader in uranium mining [2], which has been increased several times over the past 15 years due to underground leaching $[2,3]$. As a result, a considerable share of the country's export is accounted for uranium, coal and electricity. Therefore, the extraction and development of mineral resources is a strategically important task for Kazakhstan and Ukraine.

In Ukraine most of the resources are extracted with the underground method in conditions of high mining pressure. For ore deposits the main problem is efficient crushing of strong rocks [4] and ensuring the stability of workings and chambers at depths of 1115-1900 $\mathrm{m}$ [5-7], whereas in coal mines the situation is more complicated due to soft adjoining rocks, water content, disturbance of coal seams, and so on. The negative impact of these factors affects the general condition of the mine workings at depths of more than $300 \mathrm{~m}$, especially preparatory ones, which are additionally exposed to actual works.

Coal mines have recently been using the development systems that provide the maintenance of workings behind the faces and construction of protection means on the boundary with the mined-out spaces [8-10]. However, in the case of soft footwall rocks, the protection means are mostly ineffective, as they act as dies [11-13], from which the rocks are extruded into the protected workings, and together with the contraction and subsidence of the means there happen significant displacement of the roof rocks areas around the working and the final section of face. In such conditions the question of providing proper rigidity of rocks under the protection means for maintenance of operational state of the protected workings is topical.

An effective measure in the conditions of soft footwall rocks is to construct the local reinforced zones in the rocks of the footwall under the protection means, the presence of which allows transferring the load into the massif and creating a steady foundation under the protective construction. In this direction, it is necessary to conduct comprehensive research to determine the rational parameters of such zones in specific conditions.

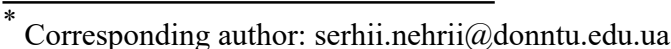




\section{Methods}

The creation of local reinforced zones on the contour of a working is achieved to ensure its rigidity. This is evidenced by the results of research presented in [14-17]. The idea of making a local reinforced zone under the means of protection was first proposed in [18]. It is provided to place such a zone in soft rocks under the protection means to ensure their rigidity by making a holistic or consolidated construction (Fig. 1) using anchors [14, 19-23] or fastening mixtures [14, 20]. This design is able to withstand the loads coming from the protection means.

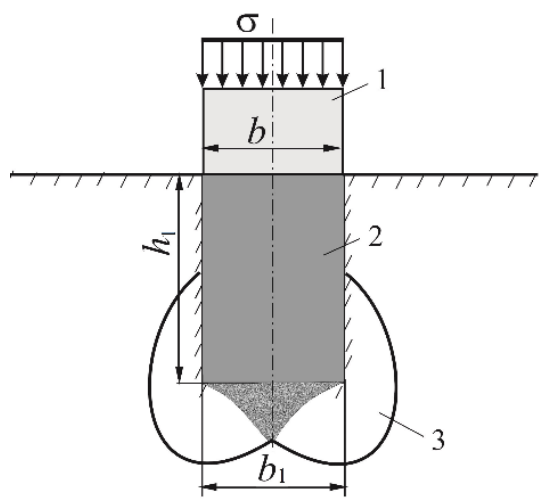

Fig. 1. Schemes of placement of protection means 1 over the local reinforced zones 2 with different shapes and deepening (1 - means of protection, 2 - local reinforced zone, 3 - area of boundary equilibrium, $\sigma$ and $b$ - respectively, the load on the protection means and its width, $h_{1}$ and $b_{1}$ - respectively, height and width of the local reinforced zone) [18].

Making under the protection means the local reinforced zone, in which the total deformation modulus is greater than the total deformation modulus of the footwall rocks, allows preparing in advance for the protective structure a rigid base that transfers load onto the massif. It increases the resistance of the footwall rocks, reduces the subsidence of the protective means according to the level of the footwall surface and reduces the displacement of the roof rocks. Since the part of the extrusion force from the foundation is directed deep into the footwall, it reduces the displacement of the footwall rocks in the working.

The efficiency of creation of such zones has been proved by the results of physical (Fig. 2) and numerical simulations (Fig. 3) [18], according to which it has been found that: laying a protective construction below the footwall surface reduces the displacement in the working and save its residual area by more than $82 \%$; the average depth of the local reinforced zone in the range of $0.8 \leq d / b<2$ can be considered effective; to determine rational parameters of the local reinforced zone under the protection means, it is sufficient to limit the parameters that determine the stress state of the underlying rocks, namely: strength and deformation characteristics of this zone under the protection means, its shape, depth and width, as well as the characteristics of the footwall rocks.
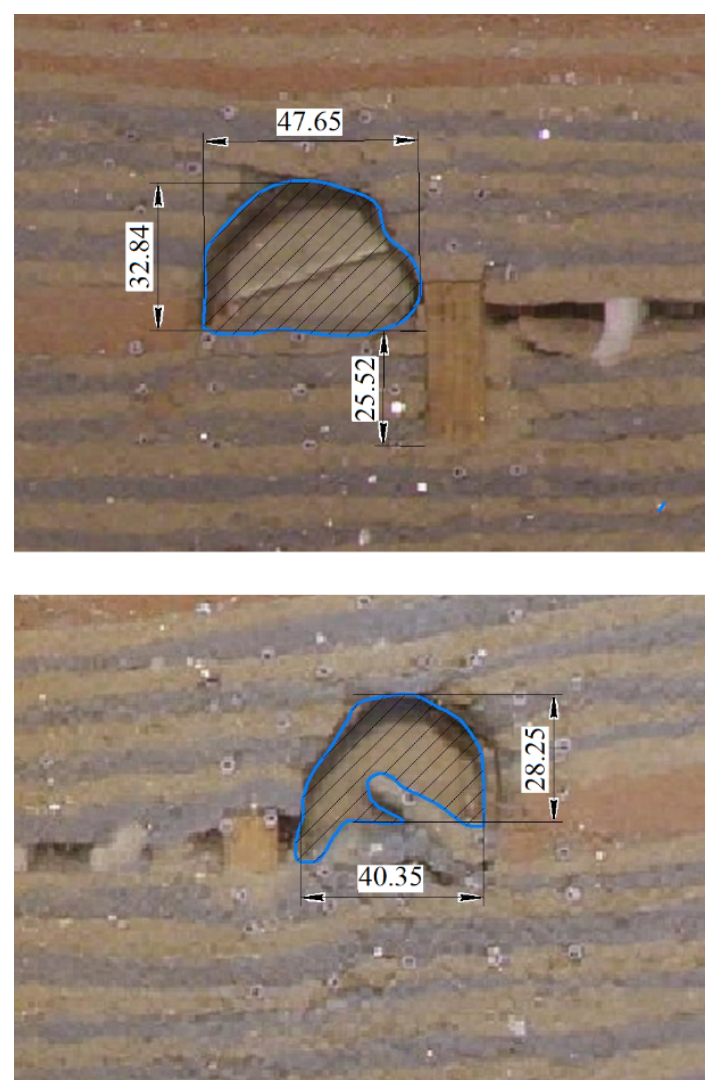

Fig. 2. General view of workings and protective constructions without deepening (a) and with deepening (b) in the model of equivalent materials at the end of measurements.
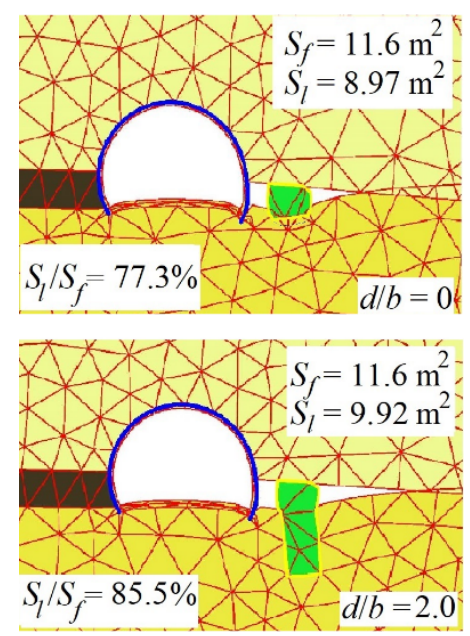

Fig. 3. General view of deformed grids of finite-element models at different relative size of depth of the protection means $d / b(d$ - value of the depth, $b$ - width of the protection means) to determine the relative residual cross section of the working $S_{k} /$ $S_{n}\left(S_{n}, S_{k}\right.$ - the cross-sectional areas of the working respectively, before and after the model calculation) [18].

In the simulations it was assumed that the means of protection were under a steady load, and the strength of the local reinforced area was equal to the strength of the material of the protection means. Therefore, the means of protection and the area under it were considered as a holistic construction. Such simplification allows to establish the range of deepening of a construction and to establish the factors which need to be considered at determining parameters of local zones. However, 
according to the results of the research, it is not possible to determine rational parameters of the zone for certain protection conditions of a working. Therefore, there is a need for additional research that would be devoted to the development of methods for determining the parameters of local reinforced zones under the protection means for specific mining, geological and technical conditions.

\section{Results and discussion}

To determine rational parameters of local reinforced zones under the protection means, it is advisable to use the results of research as for determining the displacements of adjoining rocks around these means [24] and the effectiveness of laying these zones [18].

Local fixation of the partially destroyed massif and creation the blocks with greater strength than the surrounding rocks allows preserving the integrity of this massif and promotes self-wedging of the destroyed rock blocks in the process of movement [20]. As a criterion for determining the effectiveness of making a local reinforced zone under the protection means, the value of the change in subsidence of the protective construction relative to the surface of the underlying rocks has been proposed. This criterion can be shown by the coefficient $k_{o}$. Then

$$
k_{o}=\frac{U_{b}}{U_{b}^{*}},
$$

where $U_{b}, U_{b}{ }^{*}$ - the amount of subsidence of the footwall surface under the protection means, respectively, without any measures and with the construction of a local zone, m.

The value of $U_{b}$ depends on the magnitude of the load from the protective construction, its width, the strength of the soft layer of the footwall and their compressive properties, so it can be determined from the expression [24]

$$
U_{b}=0.835 m_{v} \sigma_{o} h_{n}
$$

where $\sigma_{o}$ - are the stresses arising at the contact of the protection means and the underlying rocks because of the load, MPa; $h_{n}-$ is the thickness of the direct footwall layer, $\mathrm{m} ; m_{v}-$ is the coefficient of relative compressibility of rocks, $\mathrm{MPa}^{-1}$, which is determined by the expression [25]

$$
m_{v}=\left(1-\frac{2 \mu_{n}^{2}}{1-\mu_{n}}\right) / E_{n},
$$

where $E_{n^{-}}$is the modulus of the total deformation of the direct footwall layer, $\mathrm{MPa} ; \mu_{n}$ - is a coefficient of relative transverse deformation of this layer.

This expression has been obtained according to the results of numerical simulation. It has a coefficient of determination $R^{2}=0.9$, and correlation $-r=0.949$, which indicates a strong correlation. In addition, $t>t_{\text {critical value }}$ $(75.3>1.96)$ and $F>F_{\text {critical value }}(1883.9>2.62)$, so the relationship can be considered reliable; the correlation and determination coefficients are statistically significant, and the regression equation is statistically reliable.

According to the results of simulations [18], we can assume that the value of $U_{b}{ }^{*}$ depends on the shape of the local zone, its depth and width, as well as the strength and deformation characteristics of this zone and the underlying rocks. Peculiarities of the affect of bearing pressure on the underlying rocks depend on many factors, which include the structure and physical and mechanical properties of interlayer rocks, the angle of a seam inclination, the peculiarities of the development system, the roof control method, and the speed of a face displacement [26]. Let's limit to the parameters that must be changed in the model to establish the functional dependence: the magnitude of the load, the rigidity of the protective construction, its weight, width and height, as well as an indicator that characterizes the compressibility of the footwall rocks.

In general, the dependence of the amount of subsidence of the footwall surface under the protection means, in the presence of a local reinforced zone, from the influencing factors, may be determined by the expression

$$
U_{b}=f\left(\sigma_{o} ; b ; h_{1} ; b_{1} ; \mu_{1} ; E_{n} ; E_{1} ; \mu_{n} ; h_{n}\right),
$$

where $b$ - is the width of the protection means, $\mathrm{m} ; b_{1}, h_{1}-$ are, respectively, the width and the depth of the local reinforced zone, $\mathrm{m} ; \mu_{1}-$ is the coefficient of transverse deformations of the local reinforced zone, units; $E_{1}$ - is the modulus of total deformation of the reinforced massif in the local zone, MPa.

In dimensionless form, the dependence (4) has the expression

$$
\frac{U_{b}^{*}}{h_{n}}=f\left(\sigma_{o} m_{v} ; \frac{b_{1}}{b} ; \frac{b_{1}}{h_{1}} ; \mu_{1} ; \frac{E_{1}}{E_{n}}\right)
$$

and includes nine factors. To quantify it, we use the plan of V.M. Mordashev [27] experiment with eight options for each factor, which has the form shown in table 1.

Table 1. Initial data for the construction of numerical models when determining the parameters of local reinforced zones

\begin{tabular}{|c|c|c|c|c|c|c|c|c|c|}
\hline \multirow{2}{*}{$№$ experiment } & \multicolumn{9}{|c|}{ Value of indicators } \\
\cline { 2 - 11 } & $\sigma_{\boldsymbol{o}}, \mathbf{M P a}$ & $\boldsymbol{b}, \mathbf{m}$ & $\boldsymbol{\mu}_{\boldsymbol{n}}, \mathbf{u n}$. & $\boldsymbol{E}_{\boldsymbol{n}}, \mathbf{M P a}$ & $\boldsymbol{h}_{\boldsymbol{n}}, \mathbf{m}$ & $\boldsymbol{b}_{\mathbf{1}} / \boldsymbol{b}, \mathbf{u n}$. & $\boldsymbol{h}_{\mathbf{1}}, \mathbf{m}$ & $\boldsymbol{\mu}_{\mathbf{1}}, \mathbf{u n}$. & $\boldsymbol{E}_{\mathbf{1}} / \boldsymbol{E}_{\boldsymbol{n}}, \mathbf{u n}$. \\
\hline 1 & 4 & 1 & 0.1 & 100 & 1 & 1 & 0.25 & 0.1 & 1.5 \\
\hline 2 & 4 & 1.5 & 0.15 & 200 & 4 & 1.2 & 3 & 0.4 & 10 \\
\hline 3 & 4 & 2 & 0.2 & 400 & 5 & 1.3 & 4 & 0.45 & 1.1 \\
\hline 4 & 4 & 2.5 & 0.25 & 600 & 6 & 1.4 & 5 & 0.15 & 2 \\
\hline 5 & 4 & 3 & 0.3 & 800 & 7 & 1.5 & 0.5 & 0.2 & 3 \\
\hline 6 & 4 & 4 & 0.35 & 1000 & 8 & 1.05 & 1 & 0.25 & 5 \\
\hline
\end{tabular}




\begin{tabular}{|c|c|c|c|c|c|c|c|c|c|}
\hline \multirow{2}{*}{ № experiment } & \multicolumn{9}{|c|}{ Value of indicators } \\
\hline & $\sigma_{o}, \mathrm{MPa}$ & $b, \mathbf{m}$ & $\mu_{n}$, un. & $E_{n}, \mathrm{MPa}$ & $h_{n}, \mathbf{m}$ & $b_{1} / b$, un. & $h_{1}, \mathrm{~m}$ & $\mu_{1}$, un. & $E_{1} / E_{n}$, un. \\
\hline 7 & 4 & 5 & 0.4 & 1500 & 2 & 1.1 & 1.5 & 0.3 & 6 \\
\hline 8 & 4 & 6 & 0.45 & 150 & 3 & 1.15 & 2 & 0.35 & 8 \\
\hline 9 & 8 & 1 & 0.15 & 150 & 2 & 1.05 & 0.5 & 0.15 & 1.1 \\
\hline 10 & 8 & 1.5 & 0.1 & 600 & 8 & 1.1 & 4 & 0.35 & 3 \\
\hline 11 & 8 & 2 & 0.3 & 1500 & 3 & 1.4 & 3 & 0.25 & 1.5 \\
\hline 12 & 8 & 2.5 & 0.45 & 200 & 7 & 1.3 & 1.5 & 0.1 & 5 \\
\hline 13 & 8 & 3 & 0.2 & 1000 & 6 & 1.15 & 0.25 & 0.3 & 10 \\
\hline 14 & 8 & 4 & 0.4 & 800 & 4 & 1 & 2 & 0.45 & 2 \\
\hline 15 & 8 & 5 & 0.35 & 400 & 1 & 1.2 & 5 & 0.2 & 8 \\
\hline 16 & 8 & 6 & 0.25 & 100 & 5 & 1.5 & 1 & 0.4 & 6 \\
\hline 17 & 10 & 1 & 0.2 & 200 & 3 & 1.1 & 1 & 0.2 & 2 \\
\hline 18 & 10 & 1.5 & 0.3 & 100 & 6 & 1.05 & 1.5 & 0.45 & 8 \\
\hline 19 & 10 & 2 & 0.1 & 800 & 2 & 1.15 & 5 & 0.4 & 5 \\
\hline 20 & 10 & 2.5 & 0.35 & 150 & 4 & 1.5 & 4 & 0.3 & 1.5 \\
\hline 21 & 10 & 3 & 0.15 & 400 & 8 & 1.4 & 2 & 0.1 & 6 \\
\hline 22 & 10 & 4 & 0.25 & 1500 & 7 & 1.2 & 0.25 & 0.35 & 1.1 \\
\hline 23 & 10 & 5 & 0.45 & 1000 & 5 & 1 & 3 & 0.15 & 3 \\
\hline 24 & 10 & 6 & 0.4 & 600 & 1 & 1.3 & 0.5 & 0.25 & 10 \\
\hline 25 & 15 & 1 & 0.25 & 400 & 4 & 1.15 & 1.5 & 0.25 & 3 \\
\hline 26 & 15 & 1.5 & 0.45 & 800 & 1 & 1.4 & 1 & 0.3 & 1.1 \\
\hline 27 & 15 & 2 & 0.35 & 100 & 7 & 1.1 & 2 & 0.15 & 10 \\
\hline 28 & 15 & 2.5 & 0.1 & 1000 & 3 & 1.2 & 0.5 & 0.45 & 6 \\
\hline 29 & 15 & 3 & 0.4 & 200 & 5 & 1.05 & 5 & 0.35 & 1.5 \\
\hline 30 & 15 & 4 & 0.2 & 600 & 2 & 1.5 & 3 & 0.1 & 8 \\
\hline 31 & 15 & 5 & 0.3 & 150 & 8 & 1.3 & 0.25 & 0.4 & 2 \\
\hline 32 & 15 & 6 & 0.15 & 1500 & 6 & 1 & 4 & 0.2 & 5 \\
\hline 33 & 20 & 1 & 0.3 & 600 & 5 & 1.2 & 2 & 0.3 & 5 \\
\hline 34 & 20 & 1.5 & 0.2 & 150 & 7 & 1 & 5 & 0.25 & 6 \\
\hline 35 & 20 & 2 & 0.15 & 1000 & 1 & 1.5 & 1.5 & 0.35 & 2 \\
\hline 36 & 20 & 2.5 & 0.4 & 100 & 8 & 1.15 & 3 & 0.2 & 1.1 \\
\hline 37 & 20 & 3 & 0.1 & 1500 & 4 & 1.3 & 1 & 0.15 & 8 \\
\hline 38 & 20 & 4 & 0.45 & 400 & 6 & 1.1 & 0.5 & 0.4 & 1 \\
\hline 39 & 20 & 5 & 0.25 & 800 & 3 & 1.05 & 4 & 0.1 & 10 \\
\hline 40 & 20 & 6 & 0.35 & 200 & 2 & 1.4 & 0.25 & 0.45 & 3 \\
\hline 41 & 25 & 1 & 0.35 & 800 & 6 & 1.3 & 3 & 0.35 & 6 \\
\hline 42 & 25 & 1.5 & 0.4 & 400 & 3 & 1.5 & 0.25 & 0.15 & 5 \\
\hline 43 & 25 & 2 & 0.25 & 200 & 8 & 1 & 0.5 & 0.3 & 8 \\
\hline 44 & 25 & 2.5 & 0.15 & 1500 & 1 & 1.05 & 2 & 0.4 & 3 \\
\hline 45 & 25 & 3 & 0.45 & 100 & 2 & 1.2 & 4 & 0.25 & 2 \\
\hline 46 & 25 & 4 & 0.1 & 150 & 5 & 1.4 & 1.5 & 0.2 & 10 \\
\hline 47 & 25 & 5 & 0.2 & 600 & 7 & 1.15 & 1 & 0.45 & 1 \\
\hline 48 & 25 & 6 & 0.3 & 1000 & 4 & 1.1 & 5 & 0.1 & 1.1 \\
\hline 49 & 30 & 1 & 0.4 & 1000 & 7 & 1.4 & 4 & 0.4 & 8 \\
\hline 50 & 30 & 1.5 & 0.35 & 1500 & 5 & 1.15 & 0.5 & 0.1 & 2 \\
\hline 51 & 30 & 2 & 0.45 & 600 & 4 & 1.05 & 0.25 & 0.2 & 6 \\
\hline 52 & 30 & 2.5 & 0.3 & 400 & 2 & 1 & 1 & 0.35 & 10 \\
\hline 53 & 30 & 3 & 0.25 & 150 & 1 & 1.1 & 3 & 0.45 & 5 \\
\hline 54 & 30 & 4 & 0.15 & 100 & 3 & 1.3 & 5 & 0.3 & 3 \\
\hline 55 & 30 & 5 & 0.1 & 200 & 6 & 1.5 & 2 & 0.25 & 1.1 \\
\hline 56 & 30 & 6 & 0.2 & 800 & 8 & 1.2 & 1.5 & 0.15 & 1 \\
\hline 57 & 38 & 1 & 0.45 & 1500 & 8 & 1.5 & 5 & 0.45 & 10 \\
\hline 58 & 38 & 1.5 & 0.25 & 1000 & 2 & 1.3 & 2 & 0.2 & 1 \\
\hline 59 & 38 & 2 & 0.4 & 150 & 6 & 1.2 & 1 & 0.1 & 3 \\
\hline 60 & 38 & 2.5 & 0.15 & 800 & 5 & 1.1 & 0.25 & 0.25 & 8 \\
\hline 61 & 38 & 3 & 0.35 & 600 & 3 & 1 & 1.5 & 0.4 & 1.1 \\
\hline 62 & 38 & 4 & 0.3 & 200 & 1 & 1.15 & 4 & 0.15 & 6 \\
\hline 63 & 38 & 5 & 0.2 & 100 & 4 & 1.24 & 0.5 & 0.35 & 5 \\
\hline 64 & 38 & 6 & 0.1 & 400 & 7 & 1.05 & 3 & 0.3 & 2 \\
\hline
\end{tabular}

To establish the correlation dependence based on the expression (5), the numerical modeling by the finite element method has been performed [28]. The problem has been solved in a flat design, as the protective construction and the massif under it are elongated in plan and the stresses are distributed in a single plane. There have been constructed the geometric models of a unit thickness, which consist of the layers of direct and main 
footwall rocks with a local reinforced zone, on which evenly distributed load has been applied locally, simulating the affect of the protective means on the underlying layers (Fig. 4).

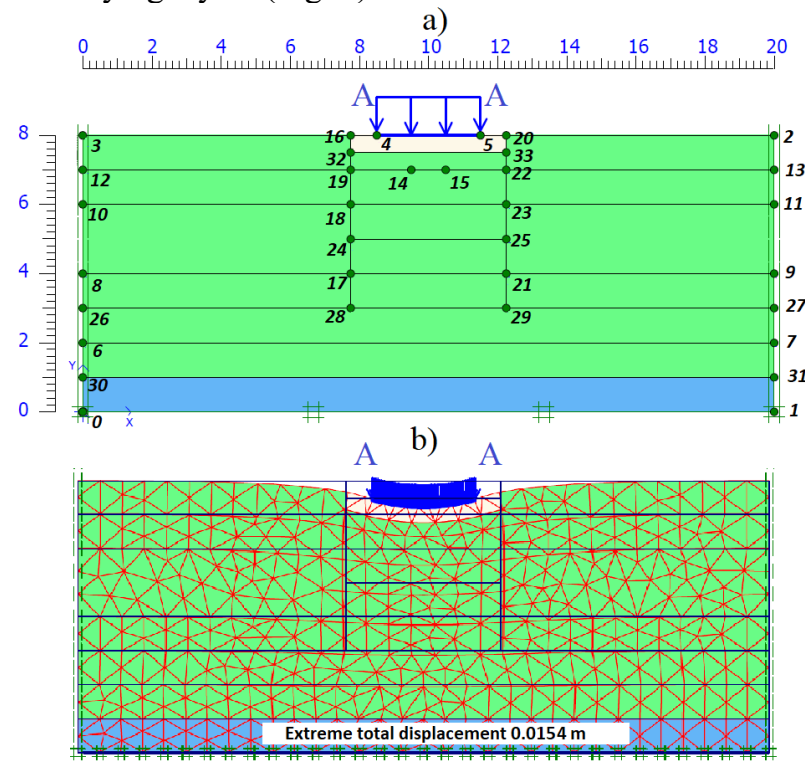

Fig. 4. Numerical model in the data entry window (a) and a finite element grid (b).

To realize the nonlinear nature of deformation of the massif, the elastic-plastic Mohr-Coulomb model has been used. According to the initial data (Table 1), 64 models have been built, during the testing of which the maximum pressing values of the footwall rocks $U_{b}{ }^{*}$ under the loading have been obtained. The general view of one of the models by the stages of its development is shown in Figure 5.

Processing of simulation results allowed to establish coefficients of empirical dependence of displacement $U_{b}{ }^{*}$ on the main affecting factors, which has the form

$$
U_{b}^{*}=0.835 \sigma_{o} m_{v} h_{n}\left(\frac{b^{2}}{h_{1} b_{1}}\right)^{0.163}\left(\frac{E_{n}}{E_{1}}\right)^{0.372}
$$

$\left(R^{2}=0.896 ; \quad t>t_{\text {critical }} \quad\right.$ value $\quad(23.1>2.0) ; \quad F>F_{\text {critical }} \quad$ value $(51.7>2.06))$, by which it is possible to determine the amount of subsidence of the protection means, under which the local reinforced zone is located.

Thus, from expressions (1), (2) and (6) it is possible to determine a relative indicator of efficiency of local strengthening of the footwall rocks by the formula

$$
k_{o}=\left(\frac{h_{1} b_{1}}{b^{2}}\right)^{0.163}\left(\frac{E_{1}}{E_{n}}\right)^{0.372},\left(\text { when } b_{1} \geq b \text { and } E_{1}>E_{n}\right),(7)
$$

which shows how much the subsidence of the protection means reduces relative to the surface of the underlying rocks when they are strengthened. It should be noted that in some cases, this figure may be less than 1 . That is, with the wrong parameters of the local reinforced zone, the effect of its presence may be negative.
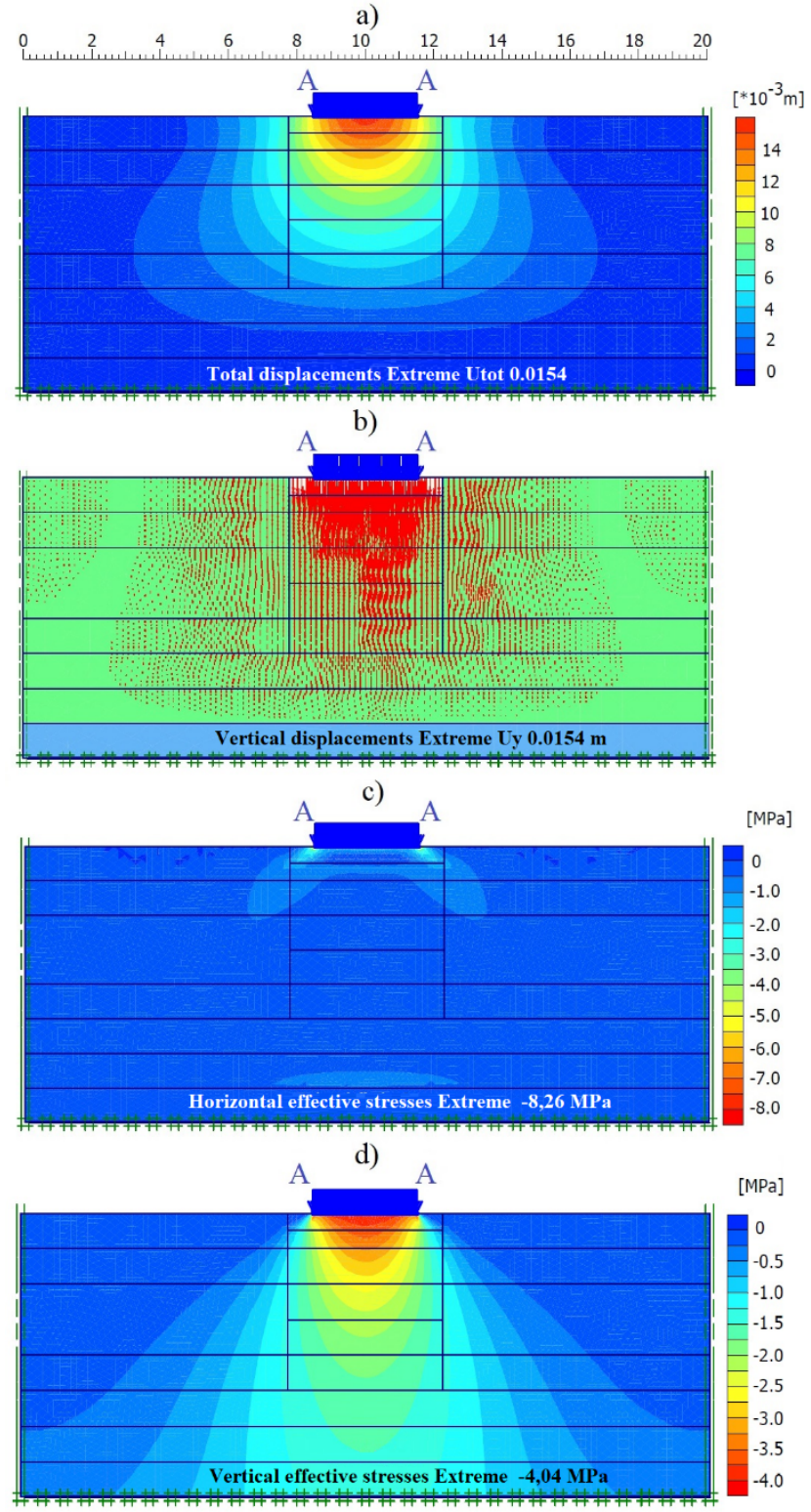

Fig. 5. General view of the numerical model for the study of deformation processes in the underlying rocks with a local reinforced zone (a- finite element grid, b, c, d- results of calculation, respectively, of vertical and horizontal stresses in the underlying rocks).

From expression (7) it follows that the parameters of the local reinforced zone under the protection means to ensure its stability are determined according to the assumption

$$
\left(\frac{h_{1} b_{1}}{b^{2}}\right)^{0.163}\left(\frac{E_{1}}{E_{n}}\right)^{0.372}>1
$$

according to which it is possible to take the appropriate size of this zone in relation to the width of the protection means and determine the required modulus of the total deformation of the zone in relation to the modulus of deformation of the soft layer of surrounding rocks. The left part of the assumption shows how much the subsidence of the protection means has been decreased with local strengthening of the footwall under it. In the 
assumption, the width of the local reinforced zone must be equal to or greater than the width of the protection means, and the deformation modulus of the local reinforced zone must exceed the deformation modulus of the soft layer of the footwall rock. Fulfillment of the condition shows the effective ratio of parameters of the local reinforced zone, the means of protection and a weak layer of footwall rocks, which increases the resistance of footwall rocks, reduces subsidence of the protection means relative to the level of the footwall surface, and reduces displacement of the roof and the protected footwall behind the face.

\section{Conclusions}

As a result of modeling the following conclusions have been made:

- the empirical dependence of the subsidence of the footwall surface under the protection means, below which the local reinforced zone is located, on the main influencing factors such as: load from the means of protection, deformation characteristics of this zone and host rocks, width of the protection means, strength of soft underlying rocks, and geometric dimensions of the local reinforced zone, has been established;

- the relative indicator of efficiency of local strengthening of footwall rocks which is used for determination of rational parameters of the given zone and considers its geometrical sizes, width of protection means, deformation and strength characteristics of a zone and host rocks, has been identified.

This work has been carried out within the framework of the project "Improvement of ways to increase the stability of mine workings in deep mines" (State registration No. 0117U004316).

\section{References}

1. K. Kopishynska, I. Shyrokova, Current state and innovative development perspectives of nuclear energy of Ukraine. Ekonomichnyi visnyk NTUU «KPI» 16, 350-359 (2019).

2. Y. Omarbekov, Kh. Yussupov, Improving the technology of uranium mining under the conditions of high groundwater pressure. Mining of Mineral

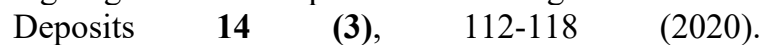
https://doi.org/10.33271/mining14.03.112.

3. E. Aben , Zh. Markenbayev, N. Khairullaev, S. Myrzakhmetov, Kh. Aben, Study of change in the leaching solution activity after treatment with a cavitator. Mining of Mineral Deposits 13 (4), 114-120 (2019).

https://doi.org/10.33271/mining13.04.114.

4. S. Pysmenniy, N. Shvager, O. Shepel, K. Kovbyk, O. Dolgikh, Development of resource-saving technology when mining ore bodies by blocks under rock pressure. E3S Web of Conferences 166, 02006 (2020). https://doi.org/10.1051/e3sconf/202016602006.

5. M.B. Fedko, I.O. Muzyka, S.V. Pysmennyi, O.V. Kalinichenko, Determination of drilling and blasting parameters considering the stress-strain state of rock ores. Naukovyi Visnyk Natsionalnoho Hirnychoho Universytetu 1, 37-41 (2019). https://doi.org/10.29202/nvngu/2019-1/20.

6. S. Pysmennyi, M. Fedko, N. Shvaher, S. Chukharev, Mining of rich iron ore deposits of complex structure under the conditions of rock pressure development. E3S Web of Conferences 201, 01022 (2020). https://doi.org/10.1051/e3sconf/202020101022.

7. N. Shvaher, T. Komisarenko, S. Chukharev, S. Panova, Annual production enhancement at deep mining. E3S Web of Conferences 123, 01043 (2019). https://doi.org/10.1051/e3sconf/201912301043.

8. V.I. Bondarenko, I.A. Kovalevska, H.A. Symanovych, O.I. Koval, V.V. Fomichov, Eksperymentalni doslidzhennia stiikosti vyimkovykh vyrobok, yaki povtorno vykorystovuiutsia na polohykh plastakh Donbasu (LizunovPres, Dnipropetrovsk, 2012).

9. S.A. Kurnosov, V.V. Zaderiy, V.I. Pilyugin, A.G. Demidenko, A.A. Tsikra, D.I. Averkin, V.V. Baldin, A.G. Silishchev, How rib-side track rigidity impacts on the gate contour convergence and eclosing rock state. Geo-Technical Mechanics 121, 160-172 (2015).

10. A.V. Martovizkiy, V.I. Pilyugin, Kontseptsiya perehoda shaht Zapadnogo Donbassa na povtornoe ispolzovanie vyirabotok. Ugol Ukrainyi 9, 11-15 (2011).

11. V.I. Bondarenko, I.A. Kovalevska and etc., Analitykoeksperymentalni doslidzhennia stiikosti vyimkovykh vyrobok i rozrakhunok parametriv kripylnoi systemy (LizunovPres, Dnipropetrovsk, 2013).

12. D.I. Averkin, Validation of Parameters for the Method of Gate Road Supporting by Concrete Packed Wall (IGTM NAS Ukraine, Dnipro, 2017).

13. V.I. Bondarenko, I.A. Kovalevska, A.V. Vivcharenko, A.V. Malyihin, Povyishenie ustoychivosti vyiemochnyih vyirabotok v sloistom massive slabyih porod. Ugol Ukrainyi 2, 8-11 (2014).

14. N.N. Kasyan, Geomechanical basis of management of a zone of the destroyed rocks around of roadway for maintenance of their stability on the big depths (DonNTU, Donetsk, 2002).

15. I. Sahno, O. Isaenkov, Y. Liashok, S. Rodzin, Sposib ukriplennia pidoshvy hirnychoi vyrobky, Patent UA 116603.

16. O. Isaenkov, I. Sahno Substantiation parameters of local soil strengthening consolidation of breeds with extensible mixtures. Journal of Donetsk Mining Institute 1(40), 35-40 (2017).

17. I. Sahno, O. Isaenkov, Y. Liashok, Sposib pidvyshchennia stiikosti porid pidoshvy hirnychykh vyrobok, Patent UA 116602.

18. S. Nehrii, T. Nehrii, S. Kultaev, O. Zolotarova, Providing resistance of protection means on the soft adjoining rocks. E3S Web Conferences 168. 00033 (2020). https://doi.org/10.1051/e3sconf/202016800033.

19. A.F. Bulat, V.V. Vinogradov, Oporno-ankernoe kreplenie gornyih vyirabotok ugolnyih shaht (IGTM NAS Ukraine, Dnipropetrovsk, 2002). 
20. V.A. Kanin, Physical and technical basics of excavation workings in conditions of unstable rocks (UkrNDMI NAN Ukrainy, Donetsk, 2010).

21. I.G. Sahno, A Geomechanical justification of parameters road bolting systems for maintaining roadway stability (DonNTU, Donetsk, 2007).

22. A.V. Solodyankin, Geomechanic models in the system of geomonitoring in deep coal mines and methods of providing stability of long workings (NGU, Dnipropetrovsk, 2009).

23. R.N. Tereschuk, A.V. Solodyankin, E.V. Maslennikov Obosnovanie parametrov ankernoy krepi dlya vyirabotok shaht, Scientific Journal «Transactions of Kremenchuk Mykhailo Ostrohradskyi National University» 4, 141-144 (2003).

24. S. Nehrii, T. Nehrii research of behavior peculiarities of soft adjoining rocks around protective means, Naukovyi visnyk DonNTU 1-2, 16-27 (2019). https://doi.org/10.31474/2415-7902-2019-1(2)-2(3)54-79.

25. N.A. Tsyitovich, Mehanika gruntov (Vyisshaya shkola, Moskva, 1983).

26. V.I. Borsch-Komponiets, Prakticheskaya mehanika gornyih porod (Gornaya kniga, Moskva, 2013).

27. M.M. Protodyakonov, R.I. Teder Metodika ratsionalnogo planirovaniya eksperimenta (Nauka, Moskva, 1970).

28. A.B. Fadeev, Metod konechnyh elementov $v$ geomehanike (Nedra, Moskva,1987) 